\title{
Protective Effects of Aqueous Extract of Baillonella toxisperma Stem Bark on Dexamethasone-Induced Insulin Resistance in Rats
}

\author{
Marius Trésor Wego, ${ }^{1}$ Sylviane Laure Poualeu Kamani $\left(\mathbb{D},{ }^{1}\right.$ David Miaffo $\left(\mathbb{D},{ }^{2}\right.$ \\ Moise Legentil Nchouwet, ${ }^{1}$ Albert Kamanyi, ${ }^{1}$ and Sylvie Léa Wansi Ngnokam (i) \\ ${ }^{1}$ Department of Animal Biology, Faculty of Science, University of Dschang, P. O. Box 67 Dschang, Dschang, Cameroon \\ ${ }^{2}$ Department of Life and Earth Sciences, Higher Teachers' Training College, University of Maroua, P. O. Box 55 Maroua, \\ Maroua, Cameroon \\ Correspondence should be addressed to Sylvie Léa Wansi Ngnokam; wansylvie@yahoo.fr
}

Received 5 January 2019; Revised 12 June 2019; Accepted 25 July 2019; Published 27 August 2019

Academic Editor: P. Patrignani

Copyright (c) 2019 Marius Trésor Wego et al. This is an open access article distributed under the Creative Commons Attribution License, which permits unrestricted use, distribution, and reproduction in any medium, provided the original work is properly cited.

\begin{abstract}
The aim of this study was to evaluate the effects of the aqueous extract of Baillonella toxisperma stem bark on dexamethasoneinduced insulin resistance in rats. A quantitative phytochemical study was done on the aqueous extract of Baillonella toxisperma for the total phenol, flavonoid, and flavonol determination. Insulin resistance was induced by intraperitoneal injection of dexamethasone $(1 \mathrm{mg} / \mathrm{kg}$ ) for 8 days, one hour before oral administration of different treatments (extract at doses of 60, 120, and $240 \mathrm{mg} / \mathrm{kg}$ and metformin at $40 \mathrm{mg} / \mathrm{kg}$ ). During the test, body weight and blood glucose level were evaluated on days 1 and 8 . At the last day of treatment, the glucose tolerance test was performed in rats; after that, blood samples were collected for triglycerides, total cholesterol, LDL and HDL cholesterols, transaminases (ALT and AST), and total protein level determination. Organs (heart, liver, pancreas, and kidneys) were also collected for the relative organ weight determination. The results showed that the aqueous extract of $B$. toxisperma is rich in total phenols, flavonoids, and flavonols. This extract significantly reversed the metabolic alterations (lipid profile, protein level, and transaminase activity) induced by dexamethasone in rats. At doses of $120 \mathrm{and} 60 \mathrm{mg} / \mathrm{kg}$, Baillonella toxisperma also significantly decreases $(p<0.05 ; p<0.01)$ postprandial hyperglycemia in insulin resistance rats. The results suggest that Baillonella toxisperma can manage insulin resistance and may be useful for the treatment of type 2 diabetes mellitus.
\end{abstract}

\section{Introduction}

Diabetes mellitus (DM) refers to a group of chronic metabolic diseases which are generally characterized by hyperglycemia, which eventually leads to damage of multiple body systems [1]. It belongs to the group of five leading important diseases causing death globally and remains a major health problem in Africa [2]. There are two main types of DM: type 1 (T1DM) and type 2 (T2DM) diabetes mellitus. T1DM is due to an impaired insulin production, while T2DM is caused by a combination of genetic and environmental factors, which lead to insulin resistance and impaired insulin secretion. T2DM is the most common form of DM. It is characterized by hyperglycemia and alterations of carbohydrate, protein, and lipid metabolism, caused by a defect in insulin production or its action. The number of people with T2DM is increasing in every country, and it is estimated that 439 million people would have T2DM by the year 2030 [3]. Many progresses in the management of diabetes mellitus using synthetic drugs have been made, but these drugs have many adverse effects. In addition, these drugs are often inaccessible to many local populations because of the difficulties in their distribution. These populations generally use plants for primary health care. Thus, traditional phytotherapeutic approaches seem to enhance an interesting potential whose development process, through appropriate scientific procedures, could offer a credible alternative to communities.

Baillonella toxisperma, belongs to the family Sapotaceae, is a big tree widely distributed throughout Cameroon, 
mostly in Douala and Yabassi $[4,5]$. It is traditionally called the "moabi." It is a large tree that dominates the dense humid forest. It can exceed $60 \mathrm{~m}$ in height. Its very straight and cylindrical bole has no shoulder, and its bark is cracked. The elongated leaves have many secondary veins and are grouped at the ends of the branches. The moabi fruit is a drupe sometimes containing several seeds [6]. The maceration of stem barks of Baillonella toxisperma is used locally in the management of diabetes mellitus [5], but there is no scientific evidence to support this claim. This study aims to scientifically validate the protective effects of Baillonella toxisperma stem bark's aqueous extract on dexamethasoneinduced insulin resistance in rats.

\section{Materials and Methods}

2.1. Chemicals. All the reagents were obtained commercially. Dexamethasone sodium phosphate, Folin-Ciocalteu reagent, sodium carbonate, sodium nitrite, aluminium chloride, sodium hydroxide, sodium acetate, gallic acid, quercetin, and catechin were purchased from SigmaAldrich, St. Louis, USA. D-glucose was purchased from EduLab Biology Kit, Bexwell, Norfolk PE389GA, UK. Diagnostic kits used for estimation of total cholesterol, triglycerides, high density lipoproteins (HDL), low density lipoproteins (LDL), total protein, alanine aminotransferase (ALAT), and aspartate aminotransferase were procured from Inmesco, innovation for medical lab, L-S 04/2009 Germany. All chemicals and reagents were of analytical grade.

2.2. Collection of Plant Material. Baillonella toxisperma stem barks were collected in Mbalmayo (Central Cameroon) in May 2014. The plant was authenticated in National Herbarium of Cameroon by comparison to the number 6608/ HNC. The stem barks were shade-dried, then powdered with a mechanical grinder, passing through a sieve, and stored in an air-tight container.

2.3. Preparation of Aqueous Extract. Powdered stem barks $(150 \mathrm{~g})$ of $B$. toxisperma were macerated in $1.5 \mathrm{~L}$ of distilled water for $48 \mathrm{~h}$ at room temperature. The mixture was then filtered through a filter paper, and the filtrate was left for fermentation for $24 \mathrm{~h}$ according to the recommendation of the tradipratician. After that, the filtrate was concentrated by evaporating water at $40^{\circ} \mathrm{C}$ in a drying oven. The percentage yield of the extract was $11.21 \%$.

\subsection{Phytochemical Analysis}

2.4.1. Determination of Total Phenols. Total phenolic content in the extracts was determined by the modified Folin-Ciocalteu method [7]. The reaction mixture consisted of $200 \mu \mathrm{l}$ of extract, $200 \mu \mathrm{l} \cdot \mathrm{ml}$ of $2 \mathrm{~N}$ Folin-Ciocalteu reagent, and $400 \mu \mathrm{l}$ of $20 \%$ sodium carbonate solution. The mixture was stirred and incubated in a water bath at $40^{\circ} \mathrm{C}$ for 20 minutes. The experiment was carried in triplicate. The absorbance was read at $760 \mathrm{~nm}$. Total phenolic content was expressed as mg/g gallic acid equivalent (mg EAG/gE) using the equation obtained from a calibration curve of gallic acid $\left(y=0.0213 x+0.0065 ; R^{2}=0.9958\right)$.

2.4.2. Determination of Total Flavonoids. Total flavonoids were estimated using the aluminium colorimetric method by Padmaja et al. [8]. In brief, $1500 \mu \mathrm{l}$ of distilled water and $30 \mu \mathrm{l}$ of sodium nitrite at $5 \%$ were added to $100 \mu \mathrm{l}$ of the extract. After $5 \mathrm{~min}$ of incubation at room temperature, $30 \mu \mathrm{l}$ of aluminium chloride (10\%) and $200 \mu$ l of sodium hydroxide (1M) were added to the mixture. The experiment was carried in triplicate. The absorbance was measured at $510 \mathrm{~nm}$. Total flavonoid content was calculated as catechin equivalent (mg $\mathrm{EC} / \mathrm{gE}$ ) using the equation obtained from the calibration curve $\left(y=0.2207 x-0.0118 ; R^{2}=0.9628\right)$.

2.4.3. Determination of Flavonol Content. Flavonol content was determined according to the method of Almaraz-Abarca et al. [9]. In test tubes containing $1280 \mu \mathrm{l}$ of distilled water, $40 \mu \mathrm{l}$ of extract $(2 \mathrm{mg} / \mathrm{ml}), 40 \mu \mathrm{l}$ of aluminium chloride $(20 \%)$, and $40 \mu \mathrm{l}$ of sodium acetate (5\%) were added. The experiment was carried in triplicate. The absorbance was measured after 30 minutes at $415 \mathrm{~nm}$. The flavonol content was calculated as quercetin equivalent ( $\mathrm{mg} \mathrm{EQ} / \mathrm{gE}$ ) using the equation obtained from the calibration curve $\left(y=0.1872 x ; R^{2}=0.9734\right)$.

2.5. Experimental Animals. Wistar albino rats of both sexes (180-250 g) were obtained from the animal house of the Department of Animal Biology, Faculty of Science, University of Dschang, Cameroon. The animals were housed at room temperature $\left(22-28^{\circ} \mathrm{C}\right)$, in natural luminosity and given standard laboratory feed and water ad libitum. All experiments were conducted in compliance with ethical guide for care and use of laboratory animals. The animals were treated in accordance with the internationally accepted standard ethical guidelines for laboratory animal use and care as described in European Community Guidelines [10].

2.6. Oral Glucose Tolerance Test. For this test, 30 overnight fasted $(14 \mathrm{~h})$ rats were used and divided into five groups of six animals each. Group 1 received distilled water, group 2 received metformin ( $40 \mathrm{mg} / \mathrm{kg}$ body weight), and groups 3 , 4 , and 5 were treated with the aqueous extract of Baillonella toxisperma (AEBT) at respective doses of 60, 120, and $240 \mathrm{mg} / \mathrm{kg}$ of body weight. One hour after administration of different treatments, D-glucose $(3 \mathrm{~g} / \mathrm{kg}$ body weight) was orally administrated to all the rats. Blood glucose was estimated using the ACCU-CHEK Active Glucometer in the blood collected at the tail vein. Blood glucose was recorded before the administration of different substances and at 30, 60,90 , and $120 \mathrm{~min}$ after D-glucose treatment.

2.7. Dexamethasone-Induced Insulin Resistance. Insulin resistance was induced by intraperitoneal injection of dexamethasone $(1 \mathrm{mg} / \mathrm{kg})$ for 8 days. Thirty-six (36) rats were weighed before treatment and then were divided into six groups of six animals each. Animals were fasted overnight 
$(14 \mathrm{~h})$ before dexamethasone treatment as described by Mahendran and Devi [11]. Group 1 served as normal control and received per os (p.o.) distilled water and intraperitoneal injection of $\mathrm{NaCl}(0.9 \%)$; group 2 served as insulin resistant control and received distilled water p.o. and intraperitoneal injection of dexamethasone; group 3 served as positive control and received metformin $(40 \mathrm{mg} / \mathrm{kg}$, p.o. $)$ and dexamethasone injection; groups 4, 5, and 6 were treated with AEBT at respective doses of 60,120 , and $240 \mathrm{mg} / \mathrm{kg}$, p.o. plus dexamethasone injection. Blood glucose and body weight were evaluated the first and last day of the treatment. At the end of the treatment, the glucose tolerance test was performed in rats.

2.8. Biochemical Analysis and Organs' Weight Determination. On the 9th day, the animals were anesthetized and blood was collected under anticoagulant (heparin). Thereafter, plasma was separated for the estimation of lipid profile, transaminases (AST and ALT), and total protein levels using commercial standard diagnostic kits. Immediately after blood collection, organs (heart, liver, pancreas, and kidneys) were removed and weighed for relative organs' weight determination.

2.9. Statistics. All the results were expressed as mean \pm SEM (standard error of mean). Data were analyzed using one-way ANOVA followed by the Tukey posttest (ALT, AST, lipid, and protein levels) and two-way ANOVA followed by the Bonferroni posttest (blood glucose variation and body weight) using Graph Pad Prism version 5.03 and SPSS logical for phytochemical analysis. $p<0.05$ was considered significant.

\section{Results}

3.1. Quantitative Phytochemical Test. The phytochemical analysis revealed that the aqueous extract of $B$. toxisperma contains a significant amount of phenols, flavonoids, and flavonols estimated at $23.09 \pm 1.92 \mathrm{mg}$ EAG/gE, $0.19 \pm 0.02 \mathrm{mg}$ $\mathrm{EC} / \mathrm{gE}$, and $0.37 \pm 0.06 \mathrm{mg} \mathrm{EQ} / \mathrm{gE}$, respectively.

3.2. Effect of AEBT on the Oral Glucose Tolerance Test in Normal Rats. Administration of AEBT resulted in a significant reduction of postprandial blood glucose concentration. The best effect was observed at dose of $240 \mathrm{mg} / \mathrm{kg}$ with a significant reduction of $50.34 \%$ from the $90^{\text {th }} \mathrm{min}$ $(p<0.05)$ which was emphasized after $120 \mathrm{~min}(69.31 \%$; $p<0.01$ ) (Figure 1).

\subsection{Effects of AEBT on Dexamethasone-Induced Insulin Resistance in Rats}

3.3.1. Effect on Body Weight. Dexamethasone significantly reduced $(p<0.001)$ the body weight of rats after 8 days of administration, except on metformin-treated rats. Treatment with the aqueous extract of $B$. toxisperma did not prevent this weight loss (Figure 2).

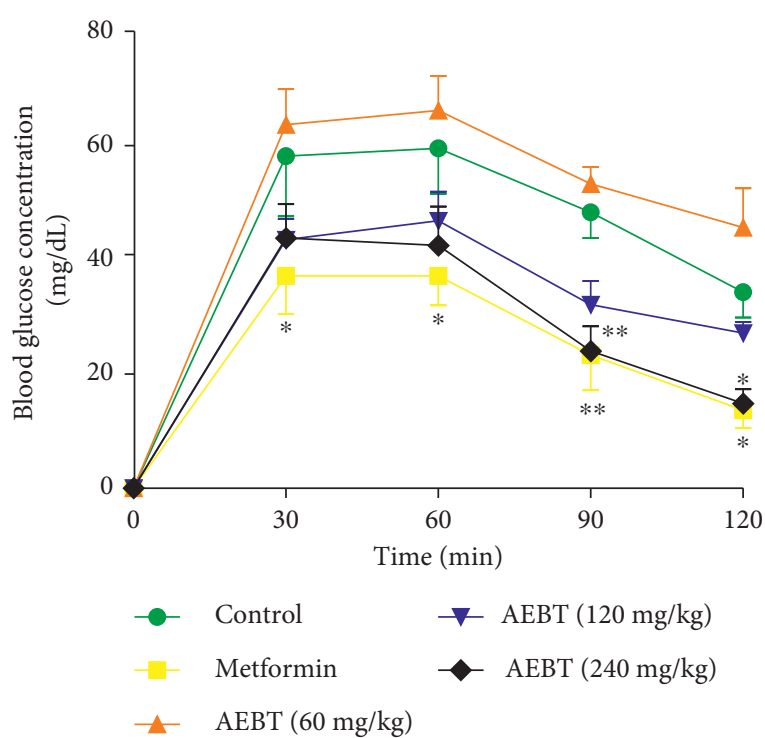

Figure 1: Effect of the aqueous extract of Baillonella toxisperma on hyperglycemia induced by $\mathrm{D}$-glucose in normoglycemic rats. AEBT: aqueous extract of $B$. toxisperma. ${ }^{*} p<0.05 ;{ }^{* *} p<0.01$ compared to the control group. $n=6$; data are presented as mean \pm SEM.

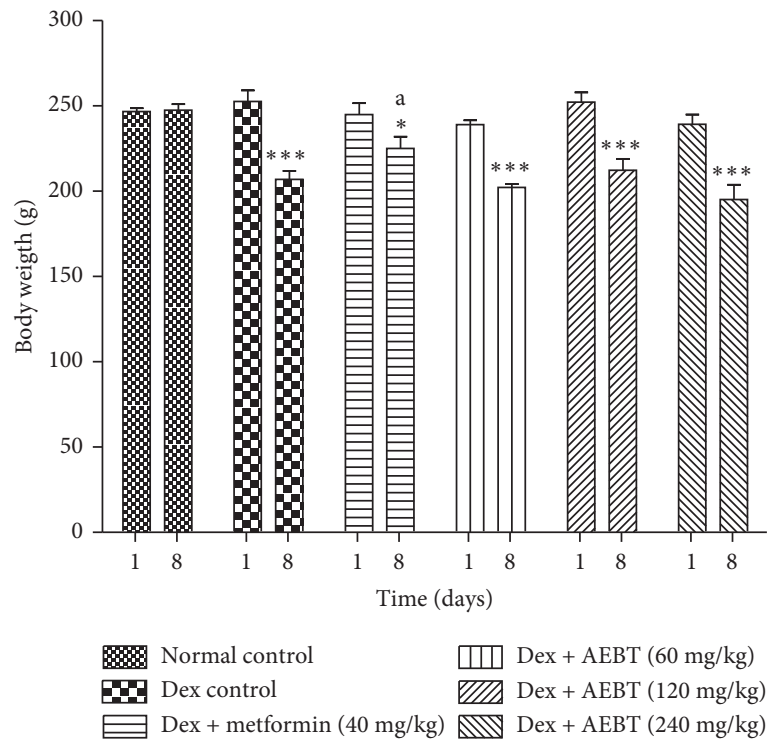

FIgURE 2: Effect of the aqueous extract of Baillonella toxisperma on body weight of insulin resistant rats. Dex: dexamethasone; AEBT: aqueous extract of $B$. toxisperma. ${ }^{* * *} p<0.001$ compared to the normal control group; ${ }^{a} p<0.05$ compared to the dexamethasone control group. $n=6$; data are presented as mean \pm SEM.

3.3.2. Effect of AEBT on the Blood Glucose Level. There was no significant variation of the blood glucose level of rats after 8 days of dexamethasone administration. However, extract at dose of $120 \mathrm{mg} / \mathrm{kg}$ significantly reduced $(p<0.05)$ the blood glucose level of rats by $29.62 \%$ compared to the dexamethasone control group (Figure 3).

3.4. Effect of AEBT on the Glucose Tolerance Test in Dexamethasone-Treated Rats. Metformin $(40 \mathrm{mg} / \mathrm{kg})$ and AEBT 


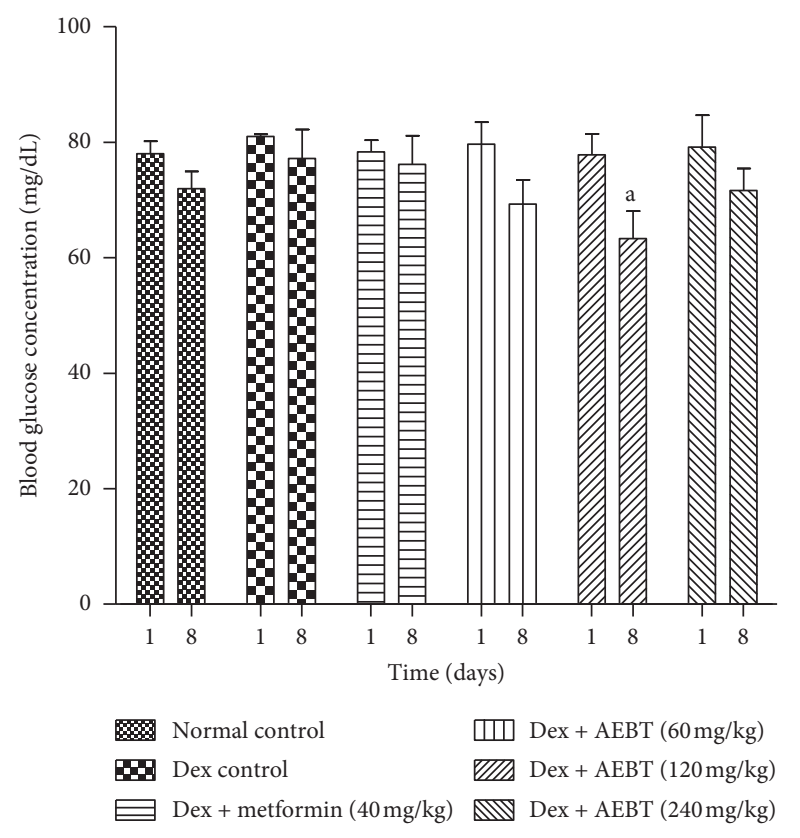

Figure 3: Effect of the aqueous extract of Baillonella toxisperma on the blood glucose level in dexamethasone-induced insulin resistant rats. Dex: dexamethasone; AEBT: aqueous extract of $B$. toxisperma; ${ }^{\mathrm{a}} p<0.05$ compared to the dexamethasone control group. $n=6$; data are presented as mean \pm SEM.

at dose of $60 \mathrm{mg} / \mathrm{kg}$ significantly reduced $(p<0.01$; $p<0.001)$ the postprandial hyperglycemia in dexamethasone rats from the $60^{\text {th }}$ to the $120^{\text {th }}$ min (Figure 4).

3.5. Effect of AEBT on Biochemical Parameters. Effects of $B$. toxisperma on biochemical parameters of insulin-resistant rats are presented in Table 1. From this table, it appears that 8 days of dexamethasone injection significantly decreased $(p<0.05)$ the total protein level of dexamethasone control rats compared to normal control rats. AEBT and metformin protected the rats against this reduction of plasma protein levels.

As shown in the same table, dexamethasone administration $(1 \mathrm{mg} / \mathrm{kg})$ significantly increased the levels of triglycerides $(p<0.01)$, total cholesterol, and LDL cholesterols $(p<0.001)$ and decreased $(p<0.001)$ the level of HDL cholesterol. However, metformin and the extract attempted to reverse this situation notably as regards the level of plasma triglycerides.

ASAT and ALAT activity significantly increased $(p<0.001)$ in dexamethasone control rats compared to normal control rats. Treatment with AEBT (120 and $240 \mathrm{mg} /$ $\mathrm{kg}$ ) significantly decreases ASAT and ALAT activity.

3.6. Effect of AEBT on Relative Organ Weight. Dexamethasone induced a significant increase $(p<0.001)$ of liver weight of rats compared to the normal control group but did not affect the other organ's weight (heart, kidneys, and pancreas). Only the metformin $(40 \mathrm{mg} / \mathrm{kg})$ treatment significantly reduced $(p<0.05)$ the liver weight gain (Figure 5).

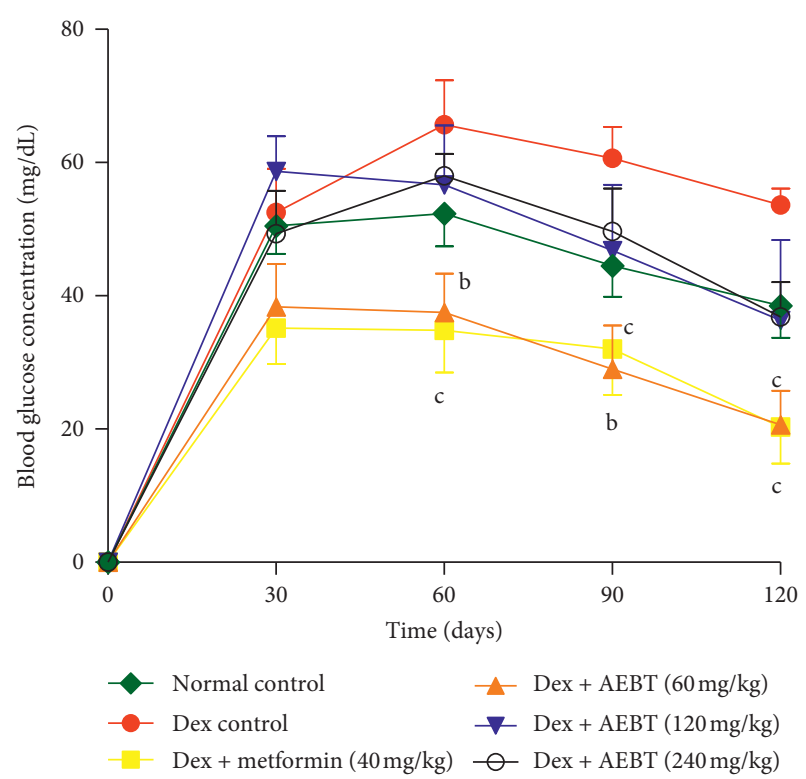

FIgURE 4: Effect of the aqueous extract of Baillonella toxisperma on the glucose tolerance test in dexamethasone-treated rats. Dex: dexamethasone; AEBT: aqueous extract of B. toxisperma; ${ }^{\mathrm{b}} p<0.01$; ${ }^{\mathrm{c}} p<0.01$ compared to the dexamethasone control group. $n=6$; data are presented as mean \pm SEM.

\section{Discussion}

Dexamethasone is a synthetic glucocorticoid whose chronic exposure to high doses causes insulin resistance [12]. In the present study, experimental induction of insulin resistance by dexamethasone at dose of $1 \mathrm{mg} / \mathrm{kg}$ administered continuously for 8 days led to profound alterations of metabolic parameters characterized by high levels of total cholesterol, LDL cholesterol, and triglyceride and low levels of HDL cholesterol, total protein, and body weight in rats.

Insulin resistance promotes the increase of hormonesensitive lipase activity of adipose tissue and the decrease of lipoprotein lipase activity. This leads to an increase in fatty acids mobilization from adipocytes and an increase in hepatic synthesis of triglycerides, which are released into the bloodstream as VLDL cholesterol [13]. According to Halimi [14], the decrease in the plasma concentration of HDL cholesterol can be explained by the presence in the circulating blood of a particular enzyme, the "Cholesterol Ester Transfer Protein” (CETP). Under hypertriglyceridemia conditions, this enzyme transfers triglycerides from VLDL cholesterol to HDL cholesterol. HDL cholesterols thus enriched with triglycerides are rapidly hydrolysed, and because of their increased catabolism, the blood level of HDL decreases. Hypercholesterolemia could be due to an increase of triglycerides in the liver, which would be responsible for an increase of the "Sterol Regulatory Element-Binding Protein"49 (SREBP) expression, a factor regulating the capture and cholesterol synthesis [13]. In this study, the various treatments administered significantly reduced triglycerides, total cholesterol, and LDL cholesterol and increased HDL 
TABLE 1: Effect of Baillonella toxisperma on biochemical parameters in dexamethasone-induced insulin resistance in rats.

\begin{tabular}{|c|c|c|c|c|c|c|c|}
\hline & $\begin{array}{c}\text { Total } \\
\text { proteins } \\
(\mathrm{g} / \mathrm{dL})\end{array}$ & $\begin{array}{c}\text { Total cholesterol } \\
(\mathrm{mg} / \mathrm{dL})\end{array}$ & $\begin{array}{l}\text { Triglycerides } \\
(\mathrm{mg} / \mathrm{dL})\end{array}$ & $\begin{array}{l}\text { HDL cholesterol } \\
(\mathrm{mg} / \mathrm{dL})\end{array}$ & $\begin{array}{l}\text { LDL cholesterol } \\
(\mathrm{mg} / \mathrm{dL})\end{array}$ & $\operatorname{ALT}(\mathrm{U} / \mathrm{L})$ & AST (U/L) \\
\hline Normal control & $6.52 \pm 0.42$ & $58.85 \pm 4.93$ & $51.25 \pm 7.51$ & $33.08 \pm 2.946$ & $15.52 \pm 6.472$ & $39.99 \pm 5.31$ & $30.19 \pm 2.49$ \\
\hline Dex control & $4.78 \pm 0.29^{*}$ & $97.94 \pm 2.60^{* * *}$ & $85.71 \pm 2.52^{* *}$ & $13.30 \pm 0.59^{* * *}$ & $67.50 \pm 2.55^{* * *}$ & $78.81 \pm 4.19^{* * *}$ & $112.5 \pm 5.60^{* * *}$ \\
\hline $\begin{array}{l}\text { Dex + Metf } \\
(40 \mathrm{mg} / \mathrm{kg})\end{array}$ & $5.26 \pm 0.54$ & $70.60 \pm 4.07^{\mathrm{c}}$ & $49.64 \pm 6.03^{c}$ & $17.22 \pm 0.36^{* * *}$ & $43.46 \pm 3.75^{* * b}$ & $54.19 \pm 5.39$ & $43.94 \pm 5.14^{\mathrm{c}}$ \\
\hline $\begin{array}{l}\text { Dex + AEBT } \\
(60 \mathrm{mg} / \mathrm{kg})\end{array}$ & $5.12 \pm 0.20$ & $70.45 \pm 4.37^{\mathrm{c}}$ & $65.71 \pm 5.29$ & $19.67 \pm 2.02^{* * *}$ & $37.63 \pm 4.81^{* c}$ & $119.7 \pm 5.80^{* * * \mathrm{c}}$ & $120.3 \pm 12.72^{* * *}$ \\
\hline $\begin{array}{l}\text { Dex + AEBT } \\
(120 \mathrm{mg} / \mathrm{kg})\end{array}$ & $5.86 \pm 0.45$ & $88.76 \pm 3.07^{* * *}$ & $46.32 \pm 5.32^{c}$ & $21.84 \pm 1.98^{* * a}$ & $57.65 \pm 4.26^{* * *}$ & $62.22 \pm 6.71$ & $79.29 \pm 9.37^{* * * a}$ \\
\hline $\begin{array}{l}\text { Dex + AEBT } \\
(240 \mathrm{mg} / \mathrm{kg})\end{array}$ & $5.72 \pm 0.39$ & $91.93 \pm 3.35^{* * *}$ & $49.45 \pm 5.28^{c}$ & $24.87 \pm 2.53^{\mathrm{b}}$ & $57.18 \pm 3.60^{* * *}$ & $17.34 \pm 6.81^{c}$ & $73.30 \pm 3.53^{* * \mathrm{bb}}$ \\
\hline
\end{tabular}

Dex: dexamethasone; AEBT: aqueous extract of $B$. toxisperma; Metf: metformin. ${ }^{*} p<0.05,{ }^{*} p<0.01$, and ${ }^{* * *} p<0.001$ compared to the normal control group; ${ }^{\mathrm{a}} p<0.05,{ }^{\mathrm{b}} p<0.01$, and ${ }^{\mathrm{c}} p<0.001$ compared to the dexamethasone control group. $n=6$; data are presented as mean \pm SEM.

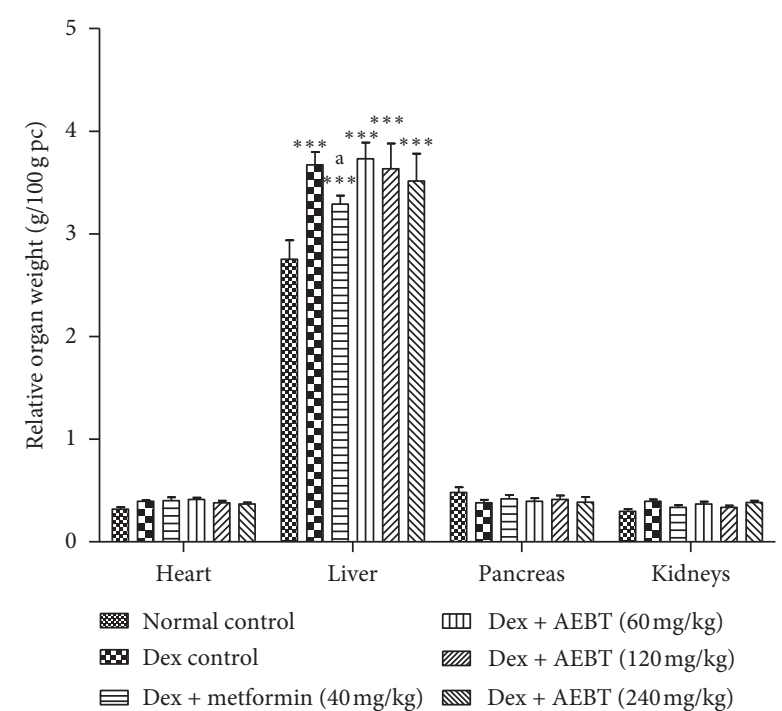

FIGURE 5: Effect of the aqueous extract of Baillonella toxisperma on relative organ weight of insulin-resistant rats. Dex: dexamethasone; AEBT: aqueous extract of B. toxisperma. ${ }^{* * *} p<0.001$ compared to the normal control group; ${ }^{a} p<0.05$ compared to the dexamethasone control group. $n=6$; data are presented as mean \pm SEM.

cholesterol levels. These results could thus reflect the ability of the aqueous extract of $B$. toxisperma to improve the tissue sensitivity to insulin, thus reducing the hormonesensitive lipase activity and increasing the lipoprotein lipase activity, resulting in a decrease of lipolysis. Aqueous and methanol extracts of $B$. toxisperma are therefore endowed with hypolipidemic properties. Flavonoids have been shown to improve dyslipidemia [15-17]. Thus, the hypolipidemic effect of $B$. toxisperma could be attributed to the flavonoids contained in the plant. These extracts could therefore effectively prevent cardiovascular complications related to diabetic dyslipidemia.

AST and ALT are markers of liver function whose release into the bloodstream results from the loss of hepatocyte membrane integrity and cell damage [18]. It is well known that glucocorticoids increase lipid catabolism. This increase of lipolysis results in a massive release of fatty acids which are accumulated in the liver [19]. This fatty acid accumulation in the liver causes hepatic steatosis, accompanied by inflammation, leading to an increase in liver mass and longterm tissue necrosis [20]. Thus, the significant increase in ALT and AST activities and relative liver weight in dexamethasone rats in this study would be due to the toxic effects of dexamethasone on the liver. The decrease in transaminase levels in animals treated with the aqueous extract indicates that $B$. toxisperma could have the ability to reverse the hepatotoxic effects of dexamethasone on the liver. This corroborates the results obtained by Bomgning et al. [21] who demonstrated the hepatoprotective properties of the aqueous and methanol extracts of $B$. toxisperma. This hepatoprotective effect could be related to polyphenolic compounds present in the plant and whose hepatoprotective effects have been demonstrated [22, 23].

In the present study, the aqueous extract of B. toxisperma protected the rats against the significant reduction of total protein levels induced by dexamethasone. This effect would reflect an insulin sensitizing effect of these extracts and, consequently, a decrease in proteolysis. The decrease in body weight and relative liver weight of rats observed was not affected by the extract.

From the results of this study, dexamethasone did not modify significantly the blood glucose of rats. However, in animals treated with the aqueous extract at dose of $120 \mathrm{mg} /$ $\mathrm{kg}$, there was a significant decrease in blood glucose. These results suggest that $B$. toxisperma extracts may also act by stimulating insulin secretion and thus have hypoglycemic effects. These hypoglycemic effects could be related to the presence of flavonoids and flavonols in the plant extract. In fact, N'diaye et al. [24] showed that these compounds possess antidiabetic properties. In normal and dexamethasonetreated rats, the aqueous extract of B. toxisperma was effective in preventing the impaired glucose tolerance. These observations suggest that $B$. toxisperma would be able to prevent dexamethasone induce insulin resistance.

\section{Conclusion}

In conclusion, our investigations indicate that the aqueous extract of $B$. toxisperma has demonstrated hypoglycemic, 
hypolipidemic, and hepatoprotective effects on dexamethasone-induced insulin resistance in rats. These effects could be due to the presence of phenols and flavonoids present in the plant.

\section{Data Availability}

The data that support the findings of this study are available from the corresponding author upon reasonable request.

\section{Conflicts of Interest}

The authors declare that there are no conflicts of interest regarding the publication of this paper.

\section{References}

[1] R. C. Gupta, D. Chang, S. Nammi, A. Bensoussan, K. Bilinski, and B. D. Roufogalis, "Interactions between antidiabetic drugs and herbs: an overview of mechanisms of action and clinical implications," Diabetology and Metabolic Syndrome, vol. 9, no. 1, p. 59, 2017.

[2] O. B. Fatai, T. T. Natu, and O. T. A. Anofi, "Antidiabetic medicinal plants used by the Basotho tribe of Eastern Free State: a review," Journal of Diabetes Research, vol. 2016, Article ID 4602820, 13 pages, 2016.

[3] P. Chamnan, R. K. Simmons, N. G. Forouhi et al., "Incidence of type 2 diabetes using proposed $\mathrm{HbA}_{1 \mathrm{c}}$ diagnostic criteria in the European prospective investigation of cancer-norfolk cohort," Diabetes Care, vol. 34, no. 4, pp. 950-956, 2011.

[4] J. Guilaumet, H. Chevillote, C. Doumengue, C. Valton, N. Fauvet, and G. Achoudong, "Atlas des essences commercialisées d'Afrique tropicale humide: l'exemple du Cameroun," in Proceedings of the 18th AETFAT Congress, pp. 770-759, Kew: Royal Botanic Garden, Yaoundé, Cameroon, January 2010.

[5] J. R. Ngueguim, J. P. Dondjang, J. Onana et al., "Moabi (Baillonella toxisperma Pierre): arbre à usage multiple de forêt dense humide du Cameroun," International Journal of Biology and Chemical Sciences, vol. 5, no. 6, pp. 2395-2406, 2012.

[6] K. Plenderleith and N. Brown, "Moabi (Baillonella toxisperma) the key non-timber forest products of Central Africa: state of the knowledge," Journal of Biodiversity and Environmental Sciences, vol. 122, pp. 32-54, 2004.

[7] A. Ramde-tiendrebeogo, A. Tibiri, A. Hilou et al., "Antioxidative and antibacterial activities of phenolic compounds from Ficus sur Forssk. and Ficus sycomorus L (Moraceae): potential for sickle cell disease treatment in Burkina Faso," International Journal of Biology and Chemical Sciences, vol. 6, no. 1, pp. 328-336, 2012.

[8] M. Padmaja, M. Sravanthi, and K. P. J. Hemalatha, "Evaluation of antioxidant activity of two Indian medicinal plants," Journal of Phytology, vol. 3, no. 3, pp. 86-91, 2011.

[9] N. Almaraz-Abarca, M. da Graça Campos, J. A. Ávila-Reyes, N. Naranjo-Jiménez, J. Herrera Corral, and L. S. GonzálezValdez, "Antioxidant activity of polyphenolic extract of monofloral honeybee-collected pollen from mesquite (Prosopis juliflora, Leguminosae)," Journal of Food Composition and Analysis, vol. 20, no. 2, pp. 119-124, 2007.

[10] EEC, "Council directive 2010/63/EU, of the $22^{\text {nd }}$ september 2010 on the approximation of laws, regulations and administrative provisions of the member states regarding the protection of animals used for experimental and other scientific purposes," Official Journal of the European Communities, vol. 276, pp. 33-79, 2010.

[11] P. Mahendran and C. Devi, "Effect of Garcinia cambogia extract on lipids and lipoproteins compositions in dexamethasone administered rats," Indian Journal of Physiology and Pharmacology, vol. 45, no. 3, pp. 345-350, 2001.

[12] E. Geer, J. Islam, and C. Buettner, "Mechanisms of glucocorticoid-induced insulin resistance: focus on adipose tissue function and lipid metabolism," Endocrinology and Metabolism Clinics of North America, vol. 43, no. 1, pp. 75-102, 2014.

[13] B. Vergès, "Pathophysiology of diabetic dyslipidaemia: where are we?," Diabetologia, vol. 58, no. 5, pp. 886-899, 2015.

[14] S. Halimi, "Dyslipidémies des diabètes et des états d'insulinorésistance," Service d'Endocrinologie-Nutrition, Université Joseph Fourier Grenoble, vol. 21, no. 7, pp. 345-346, 2000.

[15] E. E. Mulvihili and M. W. Huff, "Antiatherogenic properties of flavonoids: implications for cardiovascular health," $\mathrm{Ca}$ nadian Journal of Cardiology, vol. 26, pp. 17A-21A, 2010.

[16] M. Dong-qing, J. Zheng-ju, X. Shi-qiang, Y. Xing, H. Xia-min, and P. Hong-Yang, "Effects of flavonoids in Morus indica on blood lipids and glucose in hyperlipidemia-diabetic rats," Chinese Herbal Medicine, vol. 4, no. 4, pp. 314-318, 2012.

[17] S. Salvamani, B. Gunasekaran, N. A. Shaharuddin, S. A. Ahmad, and M. Y. Shukor, "Antiartherosclerotic effects of plant flavonoids," BioMed Research International, vol. 2014, Article ID 480258, 11 pages, 2014.

[18] S. Manokaran, A. Jaswanth, S. Sengottuvelu, J. Nandhakumar, R. Duraisamy, and D. Karthikeyan, "Hepatoprotective activity of Aerva lanata linn against paracetamol induced hepatotoxity in rats," Journal of Pharmaceutical and Technologycal Research, vol. 1, no. 4, pp. 398-400, 2008.

[19] G. Mazziotti, C. Gazzaruso, and A. Giustina, "Diabetes in Cushing syndrome: basic and clinical aspects," Trends in Endocrinology \& Metabolism, vol. 22, no. 12, pp. 499-506, 2011.

[20] E. Yamamoto, Y.-F. Dong, K. Kataoka et al., "Olmesartan prevents cardiovascular injury and hepatic steatosis in obesity and diabetes, accompanied by apoptosis signal regulating kinase-1 inhibition," Hypertension, vol. 52, no. 3, pp. 573-580, 2008.

[21] K. C. L. Bomgning, T. M. Kenfack, L. A. Fotio, K. C. Fofié, and T. B. Nguelefack, "Antioxidant and hepatoprotective effects of aqueous and ethanol extracts of the stem bark of Baillonella toxisperma," in Proceedings of the CaHReF 2016, Yaoundé Congress Hall, Yaoundé, Cameroon, 23-26 August 2016.

[22] B. A. Iwalokun, B. U. Efedede, J. A. Alabi-Sofunde, T. Oduala, O. A. Magbagbeola, and A. I. Akinwande, "Hepatoprotective and antioxidant activities of vernonia amygdalina on acetaminophen-induced hepatic damage in mice," Journal of Medicinal Food, vol. 9, no. 4, pp. 524-530, 2006.

[23] R. Rajendran, S. Hemalatha, K. Akasakalai et al., "Hepatoprotective activity of Mimosa pudica leaves against carbon tetrachloride induced toxicity," Journal of Natural Products, vol. 2, pp. 116-122, 2009.

[24] M. N'diaye, W. Diatta, G. Sy, A. Fall, B. Faye, and E. Bassene, "Activité antihyperglycémiante de l'extrait ethanolique de feuilles d'icacina senegalensis juss (Icacinaceae)," Médecine d'Afrique Noire, vol. 5509, no. 8-9, pp. 441-445, 2008. 

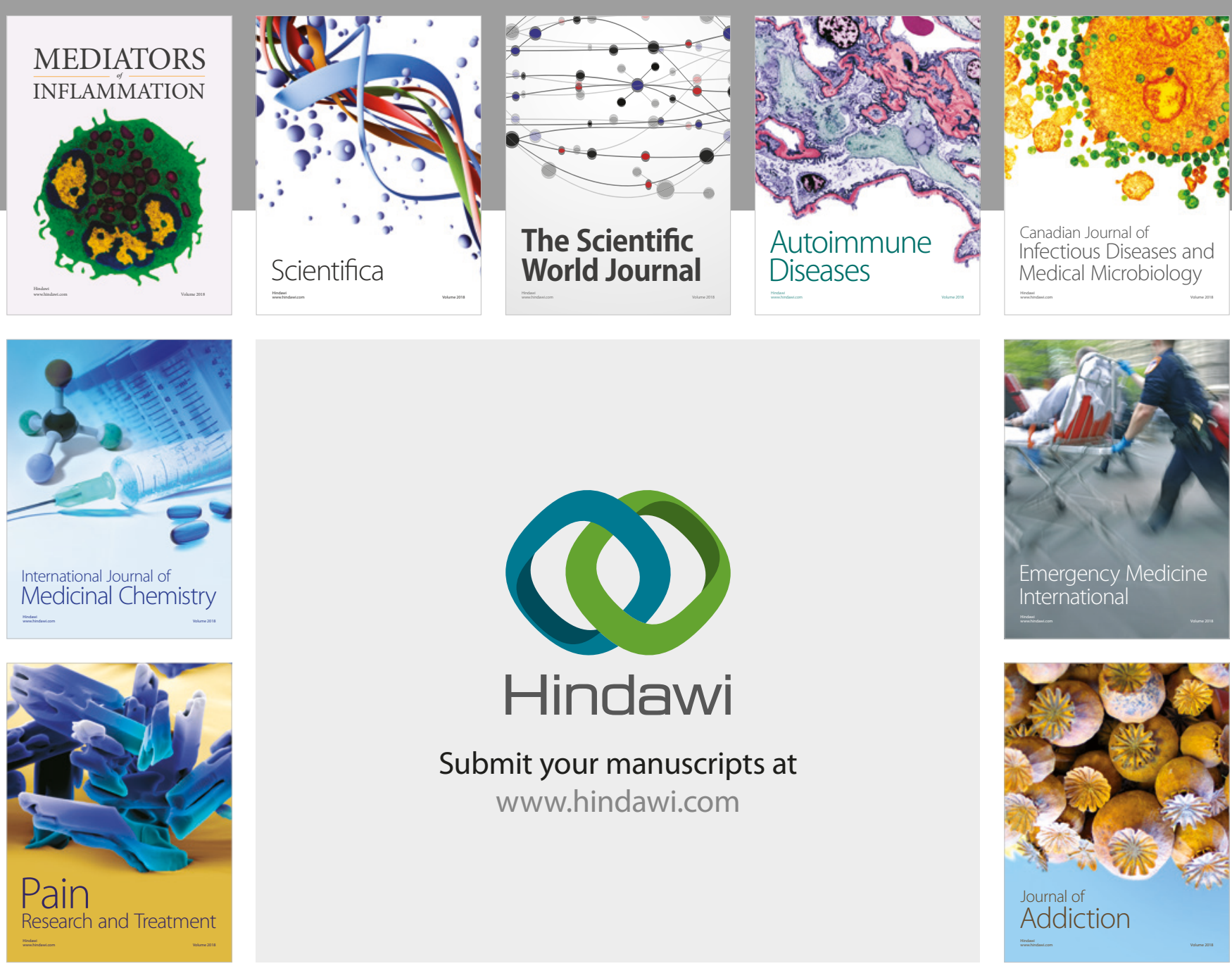

Canadian Journal of
Infectious Diseases and Medical Microbiology

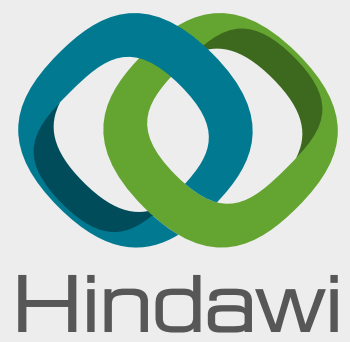

Submit your manuscripts at

www.hindawi.com
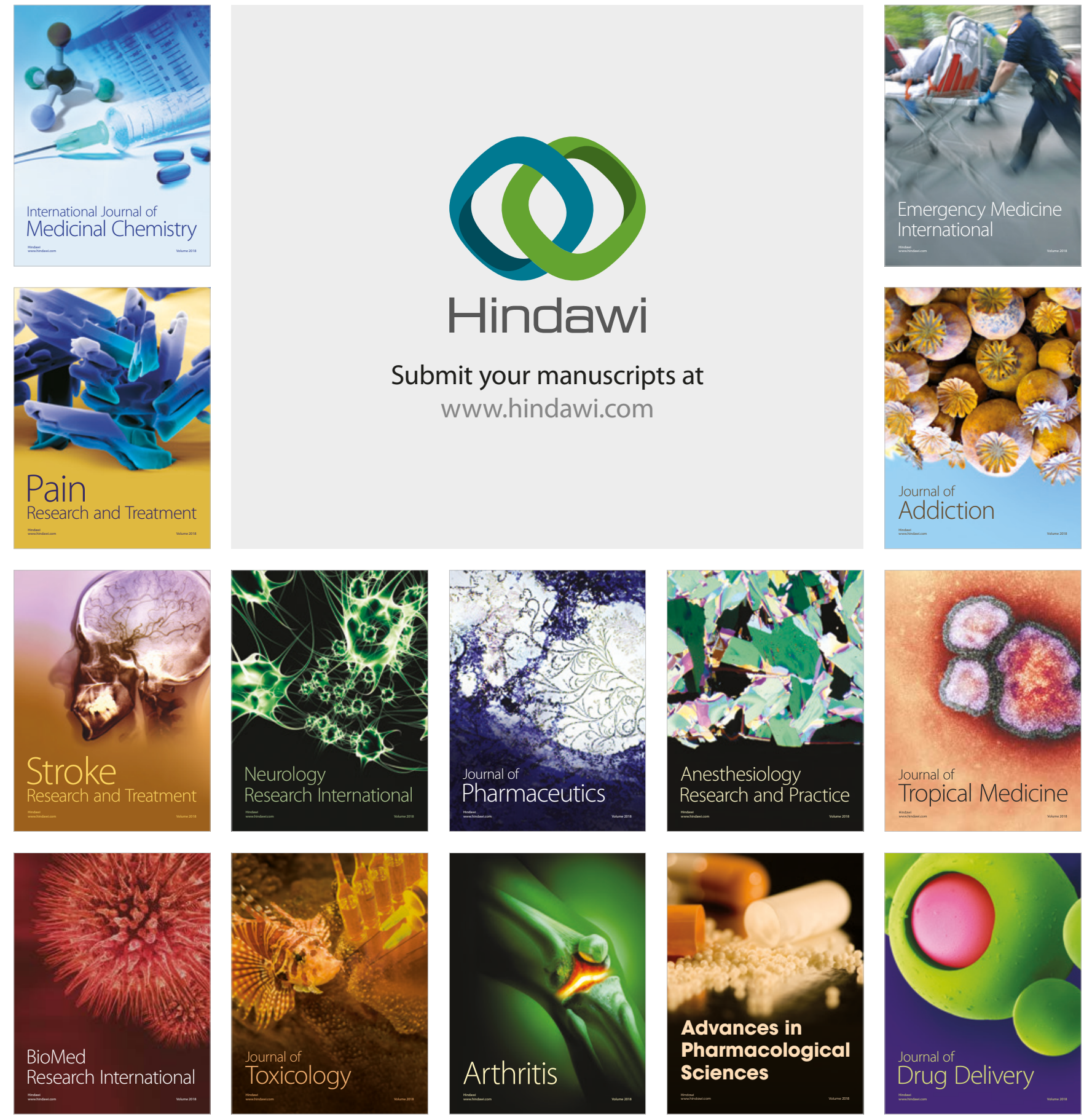